\title{
Geotectonic setting and metallogeny of the northern São Francisco craton, Bahia, Brazil
}

\author{
João Batista Guimarães Teixeira ${ }^{a, *}$, Maria da Glória da Silva ${ }^{\text {a,b }}$, Aroldo Misi ${ }^{\text {a }}$, \\ Simone Cerqueira Pereira $\mathrm{Cruz}^{\mathrm{a}}$, José Haroldo da Silva Sáa \\ ${ }^{a}$ Grupo de Metalogênese, Centro de Pesquisa em Geofisica e Geologia, Universidade Federal da Bahia, Campus Universitário de Ondina, Salvador, 40170-290, Bahia, Brazil \\ ${ }^{\mathrm{b}}$ Geological Survey of Brazil (CPRM), Av. Ulysses Guimarães, 2862, Sussuarana, Centro Administrativo da Bahia, Salvador, 41213-000, Bahia, Brazil
}

\section{A R T I C L E I N F O}

Article history:

Received 5 October 2009

Accepted 19 February 2010

\section{Keywords:}

São Francisco craton

Metallogeny

Bahia

Brazil

Palavras clave:

Cráton São Francisco

Metalogenia

Bahia

Brazil

\begin{abstract}
A B S T R A C T
This paper aims at establishing a tectonic and temporal framework to characterize the metallogenic processes that contributed to the origin of the mineral provinces in the northern São Francisco Craton. Many Archean mineralizations (eg. massive sulfide zinc, lead, zinc and copper, besides magnesite-talc, iron-titanium-vanadium, iron, chromite and manganese) were generated before the assembly of the Craton. Deposits of chromite, nickel, gold and emerald were produced during the Paleoproterozoic orogenic cycle, when the Craton was amalgamated into the Atlantica paleocontinent. An extension event is recorded in the Neoproterozoic, during the breakup of Rodinia, associated with deposits of phosphorite and uranium. Kimberlite diamond and gold mineralization were generated during the Brasiliano orogenic cycle, coeval with the amalgamation of West Gondwana. A long-lasting and rather uniform crustal stress is recorded in the area during the Cambrian period. Resetting of the isotopic and magnetic systems that affected the Neoproterozoic sediments of the Irecê Basin at about 520 Ma was attributed to the regional-scale fluid migration and mineralization in the aftermath of the Brasiliano orogenic cycle.

(c) 2010 Elsevier Ltd. All rights reserved.
\end{abstract}

\section{R E S U M O}

Este artigo visa estabelecer um quadro tectônico e temporal para caracterizar os processos metalogenéticos que contribuíram para a origem das províncias minerais no setor norte do Cráton São Francisco. Muitas mineralizações arqueanas (por ex. sulfeto maciço de zinco, chumbo, zinco e cobre, além de magnesita-talco, ferro-titânio-vanádio, ferro, cromo e manganês) foram geradas antes da formação do Cráton. Depósitos de cromo, níquel, ouro e esmeralda foram produzidos durante a orogênese paleoproterozóica, quando o cráton foi amalgamado dentro do paleocontinente Atlântica. Um evento extensional é registrado no Neoproterozóico, durante a fragmentação do paleocontinente Rodinia, associado a depósitos de fosforita e urânio. Kimberlitos diamantíferos e mineralizações de ouro foram geradas durante o ciclo orogenético Brasiliano, contemporâneo com a aglutinação do paleocontinente Gondwana Ocidental. Um regime de tensão crustal bastante uniforme e de longa duração foi registrado na região durante o período Cambriano. A reconfiguração dos sistemas isotópico e magnético que afetou os sedimentos neoproterozóicos da bacia de Irecê há cerca de 520 Ma foi atribuída ao evento tectônico de escala regional, à migração de fluidos e mineralização, como consequência do ciclo orogenético Brasiliano.

(c) 2010 Elsevier Ltd. All rights reserved.

\footnotetext{
* Corresponding author. Postal address: Rua Camuripeba, 13, Itapoan, Salvador, Bahia, 41650-035, Brazil. Tel./fax: +557133752661.

E-mail address: jbgteixeira@gmail.com (J.B.G. Teixeira).
}

\section{Introduction}

The configuration of the São Francisco Craton was established by Almeida (1977) and corroborated by Alkmim (2004). It includes the major parts of the states of Bahia and Minas Gerais, being limited by peripheral fold belts of Neoproterozoic age. Six crustal blocks of 
Archean age were identified in the cratonic basement of Bahia State, namely Gavião, Guanambi-Correntina (which extends southward into Minas Gerais), Jequié, Mairi, Serrinha and Uauá (Fig. 1).

The assembling of the São Francisco Craton in Bahia was attributed to a collision event involving the Gavião, Jequié and Serrinha blocks in the Rhyacian to Orosirian transition (Barbosa and
Sabaté, 2004). During this phase, a number of mineral deposits have been produced, including chromium and nickel.

Mantle upwelling following the post-orogenic extensional collapse produced crustal melting together with intrusion of S-type granite plutons and magma extraction from the upper mantle (Teixeira et al., 2007). Gold and emerald deposits were formed from the emplacement and cooling of these anatectic magmas.

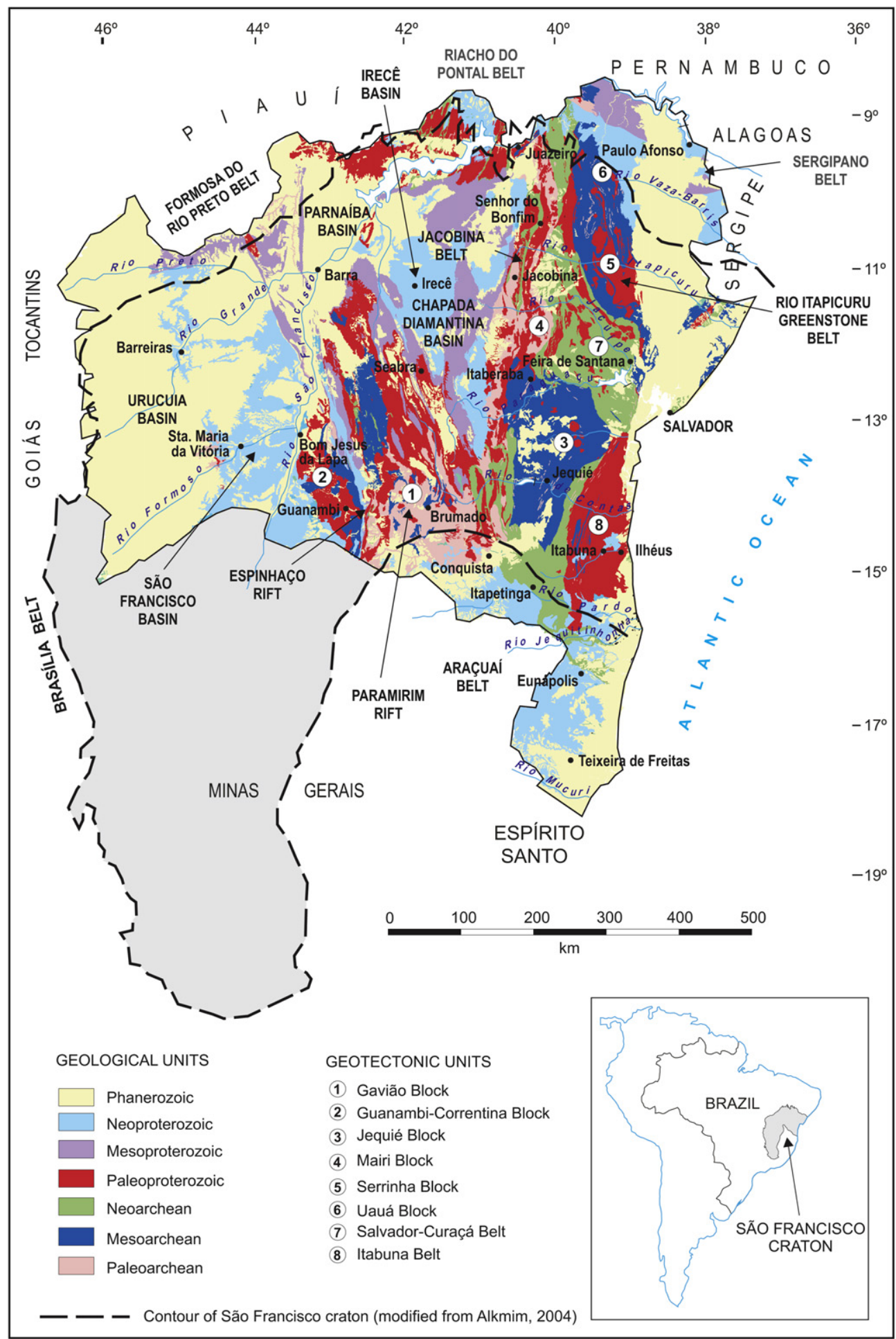

Fig. 1. Geological map of the northern São Francisco Craton (Bahia State). Geological units after Schobbenhaus et al. (2004). 
Between 1880 and 1750 Ma ago, the central sector of the São Francisco Craton experienced widespread and intermittent magmatism. The Rio dos Remédios volcanism developed in an extensional setting in central Bahia, following the initial deposition of clastic sediments of the Espinhaço Supergroup (Barbosa and Sabaté, 2004).

The Espinhaço Supergroup is divided into three groups: Rio dos Remédios, Paraguaçu and Chapada Diamantina, which are composed of several Lithostratigraphic units made of conglomerate, sandstone, pelite, carbonatic rocks, and diamictite, deposited into continental, transitional and marine systems. The continental systems were described as alluvial fan, fluvial and desertic (Silva, 1994). Diamond placer deposits are associated with this supergroup.

The Paramirim rift is a $500 \mathrm{~km}$ long and $50-100 \mathrm{~km}$ wide tectonic depression that trends NNW-SSE in the central part of the São Francisco Craton. Archean to Paleoproterozoic migmatite, granite and metamorphosed sedimentary and volcanic rocks make up the rift substratum. The Paramirim rift was interpreted as to have formed during an important extensional event marked by the emplacement of alkaline to sub-alkaline igneous complexes, including A-type granites (Arcanjo et al., 2005).

Two extensive sedimentary units of Neoproterozoic age have been deposited on the São Francisco Craton, as follows: (i) a carbonatic platform sequence in the central part, forming the São Francisco, Irecê and Una-Utinga Basins (Bambuí and Una Groups), and (ii) carbonatic and siliciclastic sequences deposited in passive margin, forming intensely deformed units in the fold belts surrounding the craton (Misi et al., 2005). The Neoproterozoic sedimentary basins in South America evolved as a consequence of extensional events during the fragmentation of Rodinia, in the Tonian-Cryogenian transition (Neves et al., 1999; Condie, 2002; Cordani et al., 2003; Misi et al., 2007). Phosphorite deposits, besides fluorite and small zinc occurrences are hosted by the Neoproterozoic sediments.

Assembling of the continental blocks of West Gondwana started around 900-700 Ma interval, with final amalgamation of the whole Gondwana around 550-530 Ma (Meert, 2001). A sequence of geodynamic and tectonothermal events that occurred from $\mathrm{ca} .600$ to $510 \mathrm{Ma}$ in the African continental area and adjacent Gondwana terranes are broadly referred to as the Pan-African Cycle, or the Brasiliano Cycle in South America. That event produced a variety of mineral deposits, including gold and diamond in kimberlite.

Following the assembling of West Gondwana, the extensional collapse of the orogen led to the production of voluminous granite plutons in the Araçuai Belt (Gomes and Oliveira, 2002; Marshak et al., 2006).

The objective of this paper is to establish a tectonic and temporal framework to characterize the metallogenic processes that contributed to the origin of the mineral provinces in the northern São Francisco Craton. Almost all of the cited references discuss the tectonic evolution and crustal structure of the involved terranes, based on isotopic geochronological evidence. The main assumption is that interpretation of high quality $\mathrm{U}-\mathrm{Pb}, \mathrm{Pb}-\mathrm{Pb}$ and $\mathrm{Ar}-\mathrm{Ar}$ analyses in carefully chosen samples can be widely used to constrain the absolute age and duration of the most common geodynamic processes, namely magmatism, anatexis, deformation, metamorphism, uplift and post-metamorphic cooling.

\section{Geotectonic setting}

\subsection{Paleoarchean to Rhyacian: cratonic components}

The Gavião block is composed of granite, granodiorite and migmatite. It includes remnants of 3.4 Ga old tonalite-trondhjemitegranodiorite (TTG) suites and associated greenstone belts. The Jequié block is characterized by Mesoarchean granulitic migmatites with supracrustal inclusions and several charnockitic intrusions (Barbosa and Sabaté, 2004). The Serrinha block is composed of orthogneiss and migmatite, which have been overthrusted by Rhyacian greenstone belts $(2.2-2.1 \mathrm{Ga})$, composed of earlier erupted Fe-rich MORBtype tholeiite and later erupted island arc andesite, associated with epiclastic and siliciclastic sediments (Silva et al., 2001).

\subsection{The Paleoproterozoic orogenic cycle}

The Paleoproterozoic orogenic belt is interpreted as part of the remnants of a large mountain chain, which extended from South America to West Africa. This orogenic cycle is called BirrimianEburnean in Africa and Transamazonian in Brazil. The postorogenic extensional collapse of the Paleoproterozoic belt in the northern São Francisco Craton took place ca. 1.9 Ga (Teixeira et al., 2007).

Geochronological constraints indicate the peak of regional metamorphism resulting from crustal thickening associated with the collision process occurred in the Orosirian, ca. $2000 \mathrm{Ma}$ ago. The exhumed roots of this Paleoproterozoic orogenic system make up the granulite-granitoid Salvador-Curaçá and Itabuna belts (Barbosa and Sabaté, 2004).

\subsection{The Mesoproterozoic extension event}

The paleocontinent Rodinia is thought to have assembled between $1300 \mathrm{Ma}$ and $900 \mathrm{Ma}$, with a major amalgamation stage occurring about 1100 Ma (Evans, 2009). Field evidence for these compressive phases, however, is missing in the São Francisco Craton (Cordani et al., 2010). The late Neoproterozoic transition from Rodinia to Gondwanaland involved rifting events that are recorded on many cratons through the interval ca. 800-700 Ma, and collisions from ca. 650-500 Ma (Evans, 2009).

\subsection{The Brasiliano orogenic cycle (Fig. 2)}

A sequence of six major stages was proposed by several authors in regard of the collisional processes during the Brasiliano orogenic cycle along the eastern region of Brazil. The timing of the formation of new crust and magmatic arcs within the cycle is not yet well understood. The list of addressed topics, presented below, indicates the nature and approximate duration of each proposed collisional stage.

- Completion of collision of the Amazon Craton in the interval of 760-780 Ma, which gave rise to the northern arm of the Brasília belt (Pimentel et al., 2000).

- Early collision ca. 750 Ma ago, involving the southern São Francisco and Rio de Plata-Paraná Cratons (Alkmim et al., 2001).

- Advanced collision in the interval of 640-620 Ma, including the Amazon Craton and generating the east-verging nappes of the southern arm of the Brasília belt (Alkmim et al., 2001).

- Creation of the Ribeira dextral-transpressional zone between 790 and $610 \mathrm{Ma}$ ago and incorporation of exotic terranes of southeastern Brazil in the Cambrian, between 535 and $500 \mathrm{Ga}$ (Heilbron et al., 2008).

- Convergence between the Rio de la Plata-Paraná and the Amazon Cratons, which gave rise to the Paraguay orogenic belt between 540 and $510 \mathrm{Ma}$ (Alvarenga et al., 2000).

- Northward progression of closure of the Brazilide ocean, which produced the dextral extrusion of the Borborema province in the Cambrian, between 540 and 500 Ma (Neves et al., 2000), along with thrusting over the northern margin of the São 


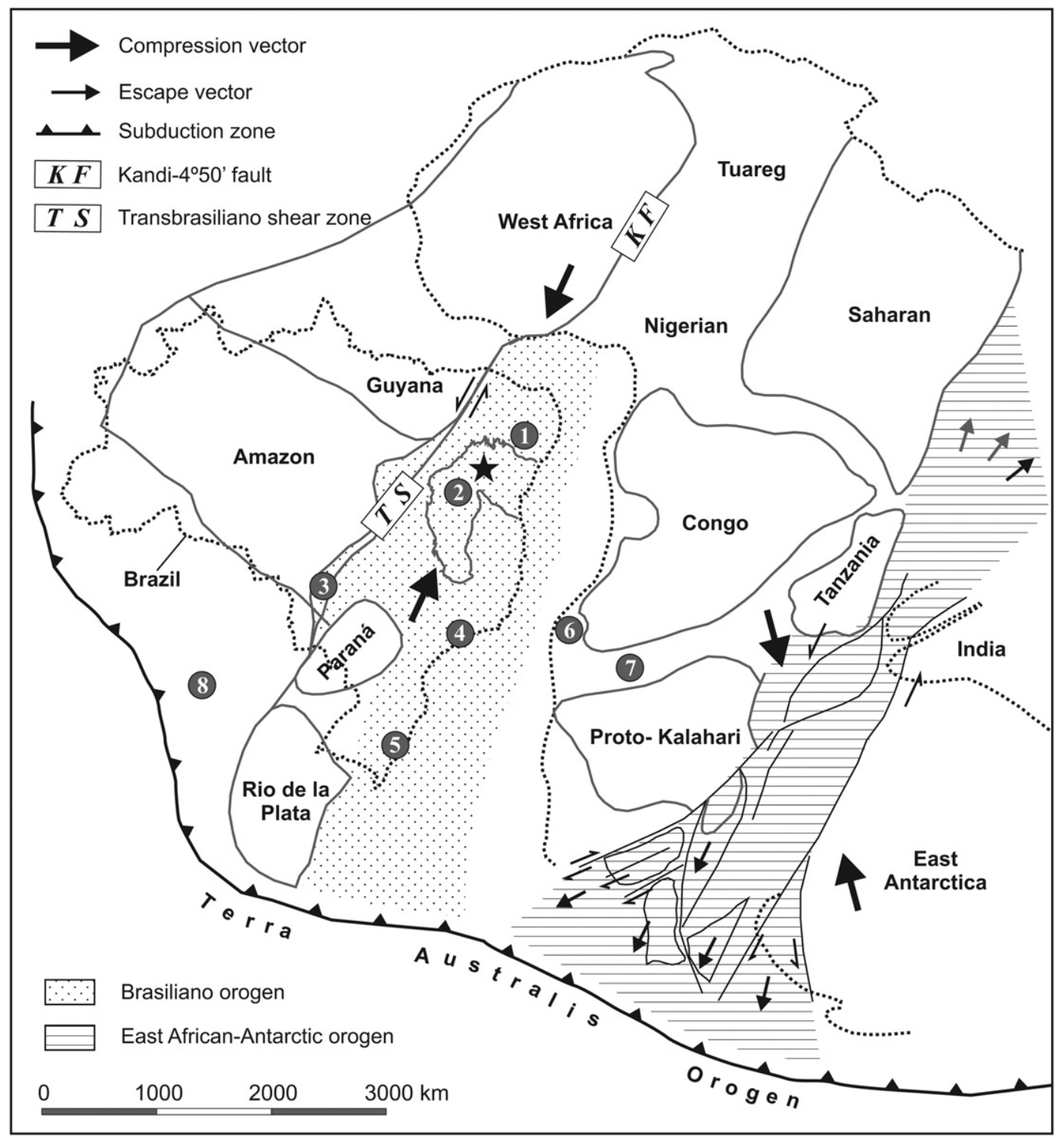

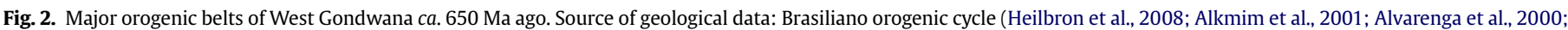

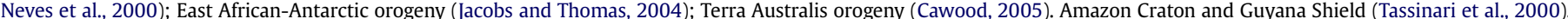

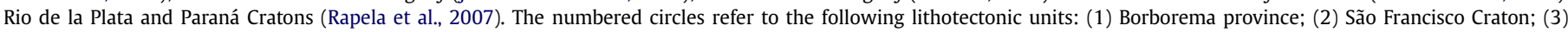

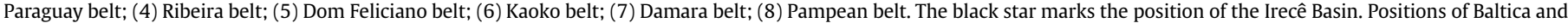
Laurentia were intentionally omitted from the present figure (in order to see the entire picture, please refer to Johansson, 2009).

Francisco Craton. Southward propagation of thrusting has caused deformation in rocks of the Paramirim Valley and of the Chapada Diamantina Basin (Alkmim et al., 2001).

\subsection{The East African-Antarctic orogeny (Fig. 2)}

The East African-Antarctic orogen resulted from the collision of various blocks of proto-East and West Gondwana between 650 and $500 \mathrm{Ma}$. This $\sim 8000 \mathrm{~km}$ long, northeast-southwest-trending collision belt enclosed a number of microplates that were amalgamated and dislocated along strike-slip faults (Jacobs et al., 1998).

At some stage of the orogeny, the strike-slip faults provided a means of tectonic transport from the collision zone toward the subduction zone of the Terra Australis orogen (Cawood, 2005), located to the south. This event was interpreted as the lateral- escape tectonics of the southern part of the East African-Antarctic orogen (Jacobs and Thomas, 2004).

\subsection{The Cambrian tectonothermal event (Fig. 2)}

Immediately after the peak of the Pan-African-Brasiliano compression, an overriding insulation condition was imposed by the thick lithosphere of the West Africa Craton, leading to progressive accumulation of thermal energy in the lithospheric mantle. The phenomenon of subcratonic heat accumulation was followed by thermal activity, which was the main cause for the circum-West Africa Craton delamination and sinking of the overthickened roots of the Pan-African-Brasiliano mountain chain (Doblas et al., 2002).

This important tectonothermal event was propagated along the border of proto-West Gondwana, between 530 and $510 \mathrm{Ma}$ 
(Heilbron et al., 2008), with its best examples described in the Búzios orogeny of the Ribeira belt (Schmitt et al., 2004), in the Kaoko and Damara belts (Goscombe and Gray, 2007), and also in the Paraguay-Araguaia (Alvarenga et al., 2000), Dom Feliciano (Bossi and Gaucher, 2004), and Pampean orogenic belts (Rapela, 2000).

\subsection{Cambrian remagnetization (Fig. 2)}

Samples of Cryogenian carbonatic rocks collected from different areas of the Irecê Basin, northern Bahia, showed similar $\mathrm{Pb}-\mathrm{Pb}$ isochron ages and paleomagnetic poles, which fall close to the $\sim 520$ Ma segment of the Gondwana apparent polar wander path, after rotation of South America to Africa. This indicates that the resetting of the isotopic and magnetic systems occurred at that particular Cambrian moment (Trindade et al., 2004).

Data from alternating field demagnetization and thermal treatments indicated monoclinic pyrrhotite, magnetite and hematite as the carriers of the more stable magnetic components in the carbonatic rocks. This Cambrian remagnetization was attributed to the regional-scale fluid migration event and mineralization in the aftermath of the Brasiliano collision (Trindade et al., 2004).

\section{Metallogenic evolution (Figs. 3 and 4 )}

\subsection{Paleoarchean zinc deposit: Mundo Novo}

The Mundo Novo zinc deposit has been investigated by Companhia Baiana de Pesquisa Mineral (CBPM) in the Paleoarchean basement of Bahia. These mineralizations were classified as volcanogenic massive sulfide (VMS) deposits with subsidiary Au, Ag, $\mathrm{Pb}$ and $\mathrm{Cu}$, hosted in volcanic and chemical sedimentary rocks of the Mundo Novo greenstone belt (Mascarenhas and Silva, 1994).

Interpretation after the first drilling phase, indicated 6 million tonnes of ore with $6.2 \%$ zinc. The ore consists of pyrrhotite, sphalerite, pyrite and chalcopyrite. The potential of the deposit along the strike and dip is still open and indicates a great potential, evidenced by well defined magnetic and electromagnetic anomalies, with good correlation with the haloes of soil geochemical anomalies (Mascarenhas et al., 1998).

The origin of the Paleoarchean greenstone belt is attributed to oceanic crust and island arc accretion that occurred at approximately 3.3 Ga ago (Oliveira et al., 2004; Peucat et al., 2002). Granite intrusion, deformation, metamorphism and hydrothermal alteration strongly affected the host rocks and sulfide orebodies of the greenstone sequence during the Rhyacian convergence.

\subsection{Paleoarchean magnesite-talc deposit: Brumado}

The first systematic work on the magnesite-talc deposit of Serra das Éguas, Brumado municipality, appeared in Bodenlos (1954). There are six mineralized areas (Pedra Preta, Jatobá, Pomba, Pirajá, Pedra de Ferro and Catitoaba), associated with the Brumado greenstone belt, of Paleoarchean age (Silva and Cunha, 1999). The host rocks are ultramafic flows containing several intercalations of dolomitic marble, which were deposited directly above the gneissic-migmatitic basement and overlied by banded iron formation. Twenty-one individual deposits have been explored, which are currently being mined by Magnesita Refratários S.A. The total reserve of magnesite ore is about $68 \mathrm{Mt}$, with $65 \% \mathrm{MgO}$ and less than $4.5 \% \mathrm{Fe}_{2} \mathrm{O}_{3}$ (Oliveira et al., 1997).

Economic talc concentrations occur in pods and veins, mostly associated with shear zones that transect magnesian marble, magnesite layers and actinolite schist (Oliveira and Ciminelli, 1997).

The origin of the magnesite of Serra das Éguas is still a matter of debate. One acceptable hypothesis considers the precipitation of
$\mathrm{Mg}^{2+}$ in hypersaline environment (Biondi, 2003). The $\mathrm{Mg}^{2+}$ bearing solutions probably originated somewhere in a neighbor sedimentary basin, and magnesitization of preexisting carbonatic rocks might have occurred if salinity, $\mathrm{CO}_{3}^{2-}$ activity, and temperature were in accordance with magnesite formation. (cf. Niedermayr et al., 1989; Dulski and Morteani, 1989).The actual mineralogy and structure of the magnesite orebodies are the result of metamorphic recrystallization and tectonic deformation.

\subsection{Neoarchean lead-zinc deposit: Boquira}

Localized about $500 \mathrm{~km}$ west from Salvador, the $\mathrm{Pb}-\mathrm{Zn}$ deposits of Boquira have been the most important sources of lead in Brazil for over 40 years, until 1991, when the reserves were exhausted. These deposits are one of the rare examples of Archean, sedimenthosted $\mathrm{Pb}-\mathrm{Zn}$ mineralizations of the world.

From 1959 until 1988 the Boquira mine produced about six million tonnes with average grades of $9-2 \%$ of $\mathrm{Pb}$ and $\mathrm{Zn}$. The massive sulfide deposits are formed by galena and sphalerite, with lesser amounts of pyrite and pyrrhotite. Gangue minerals are magnetite, maghemite, grunnerite, cummingtonite, quartz, martite, calcite and gahnite. The host rocks are banded iron formation, ferruginous quartzite, chlorite schist, amphibolite and marble (Carvalho et al., 1997).

The stratigraphic control, the character and stratiform massive mineralized bodies, the absence of volcanic rocks directly related with the mineralization and the presence of associated extensional faults, point to a hydrothermal origin, closer to the sedimentary exhalative (SEDEX) type. Lead isotope data of galena samples indicate a time span between 2.7 and $2.5 \mathrm{Ga}$ for ore deposition (Misi et al., 1999).

\subsection{Neoarchean iron-titanium-vanadium deposit: Maracás}

The Maracás deposit is hosted within gabbros and pyroxenites of the Rio Jacaré mafic-ultramafic layered intrusion emplaced in folded and metamorphosed basaltic and andesitic rocks of a Paleoarchean greenstone belt.

The sill is divided into two broad zones: (i) a $300 \mathrm{~m}$ thick lower zone, composed of massive medium-grained gabbro with cumulus olivine, clinopyroxene, magnetite and ilmenite. Mafic cumulates are made of cumulus plagioclase and clinopyroxene with minor hypersthene; (ii) a 600-1000 m thick upper zone, which consists of two subzones; the first is gabbroic to pyroxenitic and the second is gabbroic and leucogabbroic to anorthositic (Brito, 2000).

$\mathrm{Sm}-\mathrm{Nd}$ isotopic analyses indicated an age of $2841 \pm 68 \mathrm{Ma}$ for generation of the ultramafic magma (Brito, 2000).

The Rio Jacare sill is a sheetlike intrusion that extends for $70 \mathrm{~km}$ along a north-south strike averaging about $1.2 \mathrm{~km}$ in width. Magnetite pod-like bodies occur in the layered units. This massive, titaniferous magnetite mineralization at Maracás ranges from 2 to $100 \mathrm{~m}$ in thickness with an average true width of $40 \mathrm{~m}$. Mineral reserve is estimated to be 13.1 million tonnes grading $1.35 \% \mathrm{~V}_{2} \mathrm{O}_{5}$. Resource allows 8 years of milling of higher grade material at $1.94 \%$ $\mathrm{V}_{2} \mathrm{O}_{5}$ (Largo Resources, 2009).

Concentrations of platinum group elements (PGE) are associated with fine disseminated sulfides hosted within vanadium-rich titaniferous magnetite massive layers. Magnetite exhibits PGE values up to $4 \mathrm{ppm} \mathrm{Pt,} 1 \mathrm{ppm}$ Pd, and average grade of $400 \mathrm{ppb}$ total PGE (Brito et al., 2002).

\subsection{Neoarchean to Rhyacian copper deposit: Caraíba}

The Curaçá terrain in north Bahia hosts several mafic-ultramafic bodies presenting a variety of sizes. In the Curaçá River Valley, these bodies belong to the Caraíba Complex and contain economic 


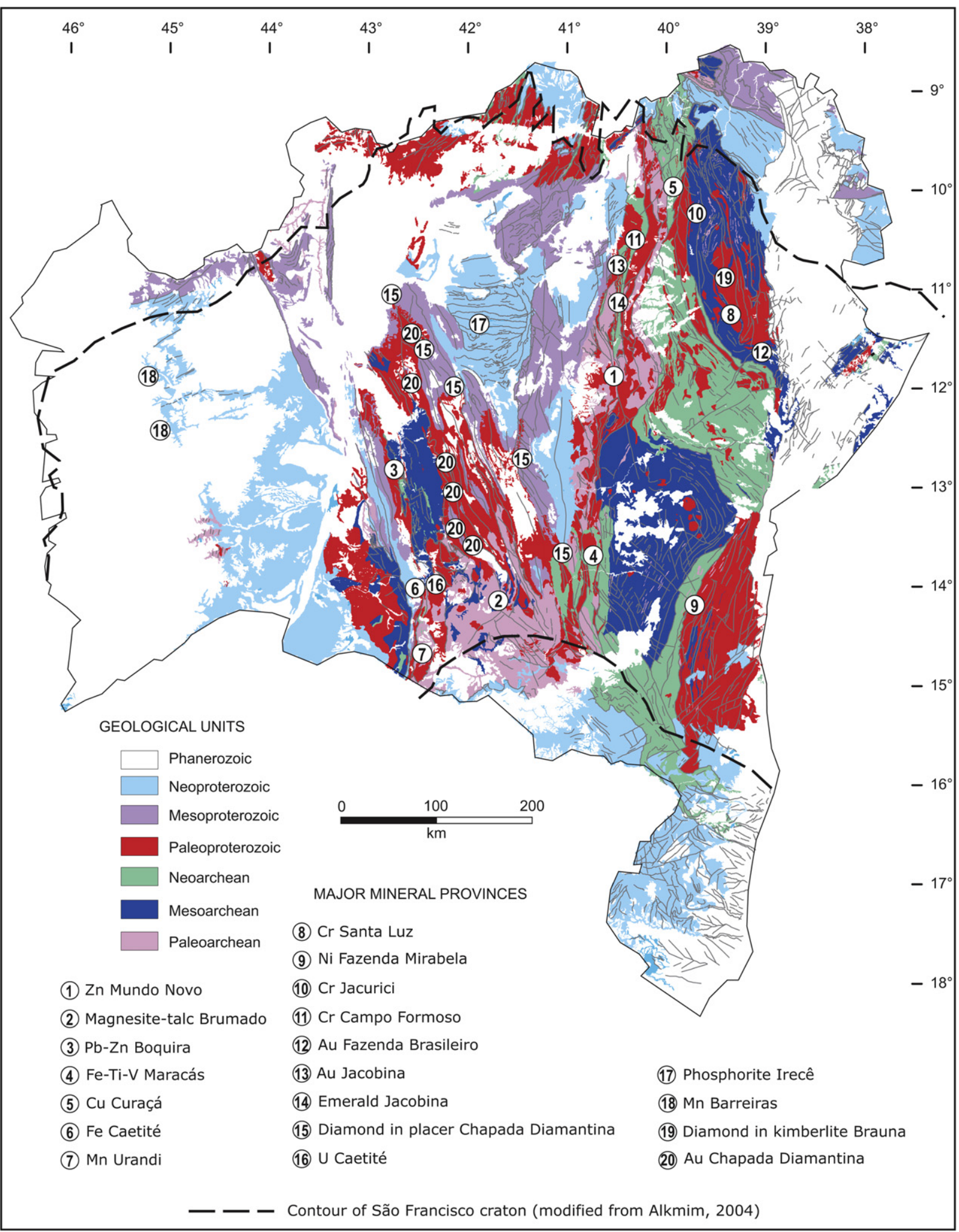

Fig. 3. Location of the major mineral provinces in the northern São Francisco Craton. Geological units after Schobbenhaus et al. (2004).

mineralization of bornite and chalcopyrite. The copper province covers an area of about $1700 \mathrm{~km}^{2}$.

The Curaçá terrain, where the Caraíba copper mine is found, is made of a basement of tonalitic to quartz-monzodioritic composition, with gabbroic levels, which underlie a supracrustal sequence of pelitic composition to the bottom and chemical composition to the top. The supracrustal rocks are graphite-rich leptinite, quartzofeldspathic gneiss, cordierite-sillimanite-garnet-biotite gneiss, amphibolite, magnetite quartzite, diopsidite and olivine marble, similar to Archean platformal sedimentary rocks (Lindenmayer, 1981). 


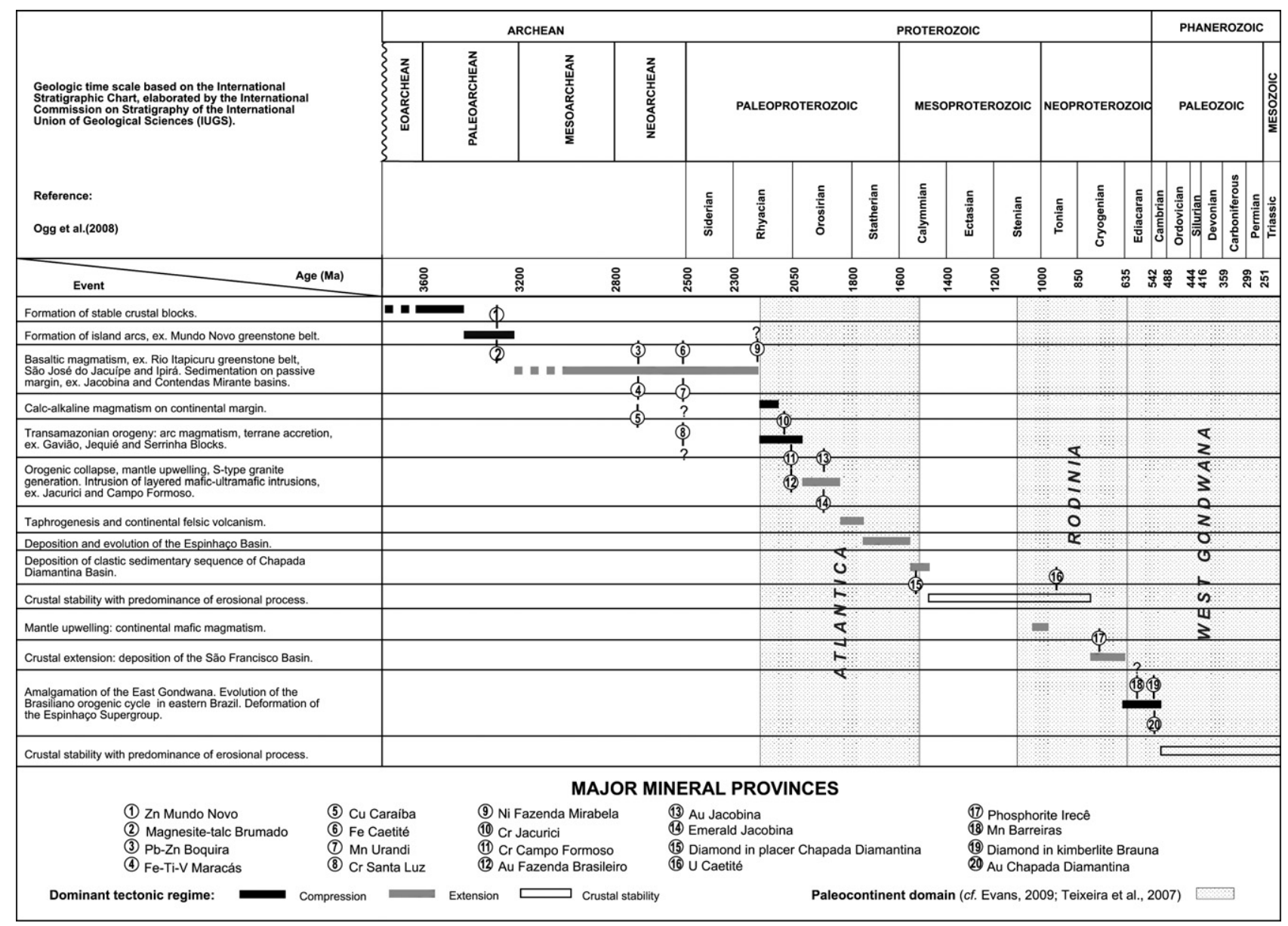

Fig. 4. Summary of the geotectonic and metallogenic evolution of the northern São Francisco Craton (Bahia State).

Samples collected near the Jacuípe river, to the southeast of Jacobina, were analysed by the U-Pb SHRIMP method, which indicated the age of $2695 \pm 12$ Ma for the formation of enderbitic orthogneiss, and of $2634 \pm 19$ Ma for the intrusion of charnockitic orthogneiss (Silva et al., 1997).

The local lithologies have been deformed and metamorphosed during at least three Paleoproterozoic tectonic phases, assisted by syntectonic, early-late $G_{1}-G_{3}$ tonalitic-granodioritic and granitic intrusions, and associated to $\mathrm{M}_{1}-\mathrm{M}_{3}$ metamorphism under high-T granulite and amphibolite facies. Deformation originated open and closed folds with vertical axial planes and with NS-oriented axes (Silva et al., 2007).

Petrological investigation of silica-undersaturated sapphirinebearing granulite enclaves in charnockite of the Curaçá Valley indicated that ultra-high temperature (UHT) metamorphic conditions were locally achieved at $\mathrm{P}-\mathrm{T}$ conditions of 7.0-8.0 kbar and 900-950 ${ }^{\circ} \mathrm{C}$. Crystallization of spinel-cordierite symplectites in sillimanite-rich and garnet-rich domains of these enclaves was interpreted as related to cooling and decompression during the orogenic evolution (Leite et al., 2009).

The Caraíba mine started in 1978 and produced about 750,000 tons of copper until 2008. The total reserve was calculated around 96 million tons of ore, at $1.82 \% \mathrm{Cu}$. The mineralized sequence contains gabbro, leucogabbro, norite, pyroxenite, hyperstenite, melanorite and biotitite, enclosed in tonalitic and charnockitic gneiss with intercalations of amphibolite, paragneiss, banded iron formation, calcsilicate rock, marble and quartzites. Enderbitic gneiss intruded by tonalite and granodiorite underlains the mineralized unit (Silva and Cunha, 1999; Silva and Oliveira, 1999; Lindenmayer, 1981).

The sulfide mineralization is almost exclusively hosted in orthopyroxenite. High concentrations of sulfides, however, can also occur in norite, biotitite (glimmerite), as well as in calcsilicate rock. The ore consists of chalcopyrite, magnetite and bornite, associated with hornblende, biotite, plagioclase, apatite and zircon. Chalcocite and ilmenite are subordinate (Lindenmayer, 1981).

Copper mineralization associated with mafic rocks, hosted by a variety of relatively small and irregular bodies, occurring in gneissic terranes is also present in Okiep, Namaqualand province, South Africa. The Okiep mineralization belongs to the noritoid Koperberg Suite, interpreted as originated from magmatic injections of high initial ${ }^{87} \mathrm{Sr} /{ }^{86} \mathrm{Sr}$ ratios. Such elevated ratios for noritoids indicate that this suite was generated from crustal material (Mclver et al., 2004).

The small noritoid bodies seem unfavorable for development of differentiation and deposition of cumulate layers, and it is possible that the current configuration of individual bodies resulted from dismembering of a larger intrusive body, as a result of shear deformation during the high-grade metamorphism. It has not been possible to identify a parental liquid for the Okiep noritoids, although McIver et al. (2004) believed the suite resulted from mantle derived alkaline magma that has undergone contamination by granitic anatexis in the lower crust.

A primary magmatic origin for the Curaçá valley copper ore should be ruled out, given the abundance of bornite and high $\mathrm{Cu}: \mathrm{Ni}$ ratio. A model that contemplates metamorphic changes under UHT 
conditions of previously formed copper mineralization would be more plausible. In order to explain the high $\mathrm{Cu}: \mathrm{Ni}$ ratio and other unusual features of the ores of the Curaçá valley, Maier and Barnes (1999) suggested that the orthopyroxenite restite resulted from melting extraction from a dioritic protolith containing sulfides, magnetite, phlogopite and apatite. The sulfides were submitted to fusion, but remained in the restite because of their high density.

Based on the above consideration, the copper mineralization of the Curaçá valley is here interpreted as the product of modification of a VMS, chalcopyrite-rich deposit that was subducted in the Archean and subjected to UHT metamorphic condition, accompanied by partial melting. During the Rhyacian convergence, the Curaçá terrain has been uplifted along a tectonic ramp and remains as one of the largest exhumed UHT terrains of the world.

\subsection{Neoarchean to Rhyacian iron deposits: Caetité}

Small to medium sized iron deposits occur to the east flank of Serra do Espinhaço, near the town of Caetité. The Caetité iron province is being explored by Bahia Mineração, a joint venture of Eurasian Natural Resources Corporation and Zamin Ferrous.

The largest deposit is the Pedra de Ferro, located $38 \mathrm{~km}$ south of Caetité. The mineralized area is between 30 and $120 \mathrm{~m}$ wide, primarily comprised of compact itabirite, friable itabirite, and friable hematite. The local country rocks are manganese-rich metasedimentary rock, schist, marble, calcsilicate rock, metabasalt and meta-andesite. Reserves are estimated at 470.5 million metric tons of iron ore with an average iron content of $40 \%$ (Bahia Mineração, 2009).

Concentrations of high-grade iron ore appeared after the sequential removal of silica of the Archean banded iron formation, giving origin to the hematite or magnetite ore. Most of the orebodies are structurally controlled throughout systems of west verging reverse faults, established during periods of thrusting and crustal thickening in the Rhyacian.

\subsection{Neoarchean (?) manganese deposits: Urandi, Caetité, and Licínio de Almeida}

Small manganese deposits occur in the basement of the Guanambi-Correntina block, near the town of Urandi, and also at the flanks of the Serra do Espinhaço.These deposits are being explored by Rio Doce Manganês S.A.

Manganese mineralization occurs as primary stratiform and rarely venular orebodies and secondary deposits, which accumulated along paleorelief uplifts. The main ore minerals are pyrolusite and cryptomelane (Ribeiro Filho, 1974).

The stratiform deposits are discontinuous and associated with schist, marble, calcsilicate rock and iron formation. The secondary deposits are poorly sorted colluvial boulders, pebbles and fragments in the sand fraction, partially cemented by iron and/or manganese oxide. Supergene alteration can be observed in soil profiles developed above the manganese formations.

A reserve of $12,340,000$ tons of ore in the basement of the Guanambi-Correntina block was estimated to the east of the Serra do Espinhaço. Grades for the primary ore range between 20 and $50 \% \mathrm{Mn}$, and there is no estimate for the secondary ore (Rocha et al., 1998).

\subsection{Rhyacian chromite deposit: Santa Luz}

The chromite deposit of Pedras Pretas is located about $2.7 \mathrm{~km}$ southeast of the town of Santa Luz. During the First World War this deposit produced between 25 and 30 thousand tons of chromite concentrate (Carvalho Filho et al., 1986).
Chromite mineralization is associated with intercalations of ultramafic rocks (pyroxenite, serpentinite, peridotite and dunite) with gabbro and anorthosite, which intruded into grey gneisses of the Archean basement and supracrustal rocks of the Paleoproterozoic Rio Itapicuru greenstone belt. The complex is older than $2085 \pm 12 \mathrm{Ma}$ and younger than $2983 \pm 8 \mathrm{Ma}$ based on $\mathrm{U}-\mathrm{Pb}$ ages obtained respectively on aplite dyke and host banded gneiss (Oliveira et al., 2007).

The chromite mine is operated by Magnesita Refratários S.A. The main orebody is approximately $250 \mathrm{~m}$ long, associated with much smaller bodies, which are all contained in a band about $1 \mathrm{~km}$ long along the direction $\mathrm{N}-\mathrm{NW}$. Their chromite reserves were estimated at $1.49 \times 10^{6}$ tons of ore containing $0.59 \times 10^{6}$ tons of $\mathrm{Cr}_{2} \mathrm{O}_{3}$ (Carvalho Filho et al., 1986).

The chromitite layers are compact or friable, and there are places with disseminated chromite grains in ultramafic rocks. Compact chromitites show major element chemistry and platinum group elements signature similar to ophiolite chromitites (Oliveira et al., 2007).

\subsection{Rhyacian nickel deposit: Fazenda Mirabela}

The Fazenda Mirabela layered intrusion lies in the southern/ southeastern part of Bahia. The local country rocks are strongly deformed charnockitic and quartzofeldspathic gneiss intercalated with metamafic rocks and iron formations.

The mafic-ultramafic body is weakly deformed, presenting cryptic and rhythmic layering and well preserved cumulate textures The intrusion is made of four lithostratigraphic layers: (i) lower zone, consisting of olivine cumulate and olivine-orthopyroxene cumulates (serpentinite, dunite and peridotite); (ii) intermediate zone, composed of orthopyroxene cumulates (orthopyroxenite and clinopyroxene norite) and clinopyroxene-orthopyroxene cumulates (websterite and gabbronorite); (iii) upper zone, composed of gabbronorite with typical gabbroic texture; and (iv) border zone, represented by fine-grained gabbronorite (Abram, 1994). Whole-rock, Sm-Nd dating, indicated a maximum age of $2.2 \mathrm{Ga}$ as possible for generation of this ultramafic magma (Silva et al., 1996). However, as the magma which produced this body underwent crustal contamination, this age must be considered as maximum (Barbosa and Sabaté, 2004).

The Mirabela mine is being operated by Mirabela Nickel Ltd. The front project is a lateritic deposit with an inferred resource of 2.32 million tonnes at a grade of $2.54 \%$ nickel. Later on, a disseminated nickel sulfide mineralization was discovered adjacent to the saprolite deposit. The drilling program for reserve determination is currently in progress. This mineralization has potential for a large tonnage, low-grade deposit. The primary nickel deposit is called Santa Rita and consists of concentrations of generally fine-grained disseminated sulfides in units from 5 to $60 \mathrm{~m}$ thick, occurring in a loosely defined zone up to $80 \mathrm{~m}$ thick. The mineralized zone occurs between the base of the peridotite and a level within the overlying pyroxenite about $10-20 \mathrm{~m}$ above its base, on the eastern side of the Mirabela ultramafic zone. Pentlandite with variable degrees of violarite alteration, together with minor pyrite are the main sulfide phases, occurring interstitial to olivine, pyroxene and chromite grains. Total sulfide abundance in the mineralized zone varies from trace quantities to 8-10 volume percent (Mirabela Nickel Ltd, 2009).

\subsection{Rhyacian chromite deposits: Jacurici}

The major chromite deposits of Brazil are in the Jacurici valley district, Bahia, Brazil. The chromitite bands are hosted by post- 
collisional, differentiated mafic-ultramafic sills, which crystallized around $2085 \mathrm{Ma}$ (Oliveira et al., 2004).

The intrusions are aligned along a north-south belt, which extends for $70 \mathrm{~km}$ in the granulite-gneiss terrane of the Caraíba Complex. The most important mineralization is contained in the Ipueira-Medrado sill, a single intrusion that has been tectonically disrupted by faulting and folding into two segments that occur on the limbs of a synform. The enclosing rocks are quartzofeldspathic gneisses that include serpentine-bearing marble, calcsilicate rocks and metachert. The sill is composed of dunite, harzburgite and pyroxenite. The ore is mined from a single, $5-8 \mathrm{~m}$ thick chromitite layer, which is continuous but structurally disrupted, within the $300 \mathrm{~m}$ thick sequence of cumulate rocks (Marques and Ferreira Filho, 2003).

\subsection{Rhyacian chromite deposits: Campo Formoso}

Another important chromite mineralization is found in the Campo Formoso district, located $350 \mathrm{~km}$ northwest of Salvador. The chromite layers occur within a $40 \mathrm{~km}$ long and $1100 \mathrm{~m}$ wide metaperidotite intrusion that contours the outer limit of the Orosirian, S-type Campo Formoso granite (Deus et al., 1982).

The ultramafic rocks are underlain by granulites of the Caraíba Complex, and are unconformably overlain by quartzite and phyllite of the Jacobina Group. The primary textures and igneous minerals have been destroyed by greenschist metamorphism and hydrothermal alteration, even though peridotite, pyroxenite and gabbroic layers have been identified by Hedlund et al. (1974).

\subsection{Rhyacian gold deposit: Fazenda Brasileiro}

Syncollisional, orogenic-type, Rhyacian gold deposits are found in the Rio Itapicuru greenstone belt, Serrinha block, São Francisco Craton (Silva et al., 2001; Teixeira et al., 2002). Fazenda Brasileiro is the most important of these deposits, which started producing in 1984 from heap leaching operation. In 1988, production began from underground mining with ore processed in carbon-in-pulp (CIP) plant, and has been in continuous operation since then. Total production is currently $95,000-100,000$ ounces of gold per year. CIP mill recoveries have averaged $92.1 \%$ and have been very consistent on a year-by-year basis. Proven and probable reserves were calculated at 2.72 million tons of ore at $3.0 \mathrm{~g} \mathrm{Au} / \mathrm{t}$ by December 2007 (Yamana Gold, 2009).

The Fazenda Brasileiro orebodies are at the borders of a $10 \mathrm{~km}$ long differentiated sill, which intrudes the contact zone between tholeiite metabasalts and intermediate, calc-alkaline metavolcanic rocks. The main host to the mineralization is a quartz-chlorite-magnetite schist, which resulted from the deformation and hydrothermal alteration of a ferrogabbroic protolith. Gold occurs as free fine-grained particles $( \pm 20 \mu \mathrm{m})$, or accompanied by sulfides (arsenopyrite, pyrrhotite and pyrite) in quartz-carbonate-albite veins and in their alteration haloes (Teixeira et al.,1990). The best estimate for the age of the hydrothermal alteration was provided by Mello et al. (2006), who dated hydrothermal muscovite with the $\mathrm{Ar}-\mathrm{Ar}$ method and revealed the ages of $2050 \pm 4 \mathrm{Ma}$ and $2054 \pm 2 \mathrm{Ma}$.

\subsection{Orosirian gold deposits: Jacobina}

Post-collisional gold deposits in the Serra de Jacobina region are in a belt of siliciclastic metasedimentary rocks intercalated with mafic and ultramafic rocks and underlain by tonalitetrondhjemite-granodiorite gneiss-(TTG) basement. The majority of the gold occurrences is hosted by quartz pebble conglomerates and resembles placer-type deposits. However, structurally controlled hydrothermal orebodies, and the occurrence of gold also in quartzites and mafic and ultramafic rocks, support an epigenetic model for the mineralization (Teixeira et al., 2001).

The main thrust and strike-slip events, related with the Jacobina Basin inversion, were interpreted to have taken place from 1940 to $1910 \mathrm{Ma}$, as indicated by $\mathrm{Ar}-\mathrm{Ar}$ cooling ages of synkinematic biotite, muscovite and fuchsite (Ledru et al., 1997). Gold mineralization in Jacobina was therefore interpreted as an integral part of the 1900 Ma tectonothermal evolution of the region (Teixeira et al., 2001, 2002).

\subsection{Orosirian emerald deposits: Jacobina}

The most important emerald occurrences of Brazil are in the Carnaíba and Socotó districts, in the Serra de Jacobina, Bahia. Beryl associated with molybdenite and scheelite occurs in phlogopite-schist bands that were formed by metasomatic reaction between aplopegmatites and serpentinites (greisenization). These mineralization processes have taken place within the metamorphic aureole of the $1.9 \mathrm{Ga}$ S-type granites, which intruded the Archean gneiss-migmatite basement and also the quartzites of Serra de Jacobina (Santana et al., 1995).

\subsection{Calymmian diamond placer deposits: Chapada Diamantina}

The diamond province of Chapada Diamantina is located in central Bahia State, spreading over the municipalities of Lençóis, Andaraí, Mucugê and Morro do Chapéu. This region was internationally famous in the nineteenth century because of its diamond production. In 1844, diamonds were discovered in Serra do Sincorá, Mucugê region and exploitation started in the gravel produced by the decomposition of oligomictic conglomerate. Mining was concentrated in the region between Andaraí and Igatu, where several old mine dumps can still be seen along the access road. After an intensive exploration that lasted about 25 years, mining has declined from 1871 until nowadays (Silva, 2001).

The diamond province extends for more than $300 \mathrm{~km}$ in the NW-SE direction. Diamond occurs in conglomerates of the Tombador and Morro do Chapéu Formations, of the Chapada Diamantina Group and alluvial and colluvial deposits originated by weathering and erosion of the conglomerate beds. The conglomerates of Tombador Formation were deposited mainly by braided river systems (Dardenne and Schobbenhaus, 2003) in a time interval older than $1515 \mathrm{Ma}$ (Battilani et al., 2007).

\subsection{Tonian uranium deposits: Caetité}

The most important uranium mineralizations of South America, which are being exploited by Indústrias Nucleares Brasileiras (INB), occur in the southeastern part of state of Bahia, Municipality of Caetité, associated with A-type granites of the Lagoa Real Complex. This complex includes a range of $\sim 1700 \mathrm{Ma}$ anorogenic bodies that intruded migmatite orthogneiss and greenstone belts of the Gavião block (Costa et al., 1985; Arcanjo et al., 2005; Cruz et al., 2007).

The Lagoa Real Suite was early interpreted as cogenetic and chronocorrelative with the Rio dos Remédios felsic volcanic rocks, which have been generated from the partial melting of material derived from the continental crust (Turpin et al., 1988; Cordani et al., 1992; Pimentel et al., 1994; Cruz et al., 2007).

On the other hand, Pimentel et al. (1994), Cruz and Alkmim (2006) and Cruz et al. (2007) proposed that deformation and metamorphism of the Lagoa Real Suite have occurred from the 
Neoproterozoic to the Cambrian, most probably between 820 and $500 \mathrm{Ma}$, in conformity with the effects of the Brasiliano orogenic cycle.

The uranium mineralization is controlled by shear zones that cut the granites and laterally turn these rocks into gneisses. These shear zones host albitite bodies that resulted from hydrothermal-metasomatic alteration of the ore-bearing granites. Microclinites and oligoclasites occur as well, spatially associated with gneissic rocks and concordant with their foliation, indicating that these metasomatic rocks have been generated concurrently or after the deformation, as proposed by Lobato (1985) and Lobato and Fyfe (1990). Cruz et al. (2007), based on petrographic and textural features, proposed that albitization have occurred prior to deformation.

Maruèjol et al. (1987) and Chaves et al. (2007) stated that uranium has been leached from accessory minerals of the granites in response to the percolation of cogenetic, late-magmatic fluids. An isotopic $\mathrm{U}-\mathrm{Pb}$ age of $1395 \pm 9$ Ma was interpreted as the age of primary mineralization, and another of $480 \pm 7$ Ma was interpreted as the age of tectonic reactivation during the Brasiliano orogenic cycle (Turpin et al., 1988).

$\mathrm{U}-\mathrm{Pb}$ dating in zircons of granites and albitites and titanite of albitites using conventional thermal ionization mass spectrometry (TIMS) yielded the following results: (i) the zircons provided Statherian ages of about $1724 \pm 5$ Ma (Turpin et al., 1988), chronocorrelative with the opening of the Espinhaço rift; (ii) four fractions of titanite of albitites have shown anomalous levels of uranium, indicating these phases are coeval with the U-mineralization. These minerals produced discordant ages (showing they have suffered significant loss of $U$ after their crystallization) with upper intercept at $961 \pm 22 \mathrm{Ma}$ and lower intercept around $487 \pm 7 \mathrm{Ma}$ (Turpin et al., 1988). Using these geochronological data, Pimentel et al. (1994) proposed the melting of granites at $1746 \pm 5 \mathrm{Ma}$ (extensional environment), the generation of albitites and uranium mineralization by ca. $961 \pm 22 \mathrm{Ma}$, and the reworking of ore and host rocks during the final stages of the Brasiliano orogenic cycle.

\subsection{Cryogenian phosphorite deposits: Irecê}

Phosphorite deposits occur in dolomitic facies of the Una Group, Irecê Basin, Bahia, at the top of laminated limestones, equivalent to the Sete Lagoas Formation of the Bambuí Group. The phosphate mineralization is mainly carbonate fluorapatite, positioned at a slightly lower stratigraphic position in relation to a sulfide-rich zone. The phosphate-bearing columnar stromatolitic structures in dolostone were formed in sub- to intertidal zones and carbonate fluorapatite was formed during the early diagenetic evolution of the carbonatic sediments (Misi and Kyle, 1994).

Although these phosphorites are intimately associated with stromatolites, most of the stromatolitic structures present in these sequences are not mineralized. The phosphorite deposits of the Neoproterozoic sedimentary sequences of the São Francisco Craton are probably related to a global episode of phosphatization during the Cryogenian. Phosphate concentrations, probably related to replacement of organic structures during early diagenetic stages (Misi and Kyle, 1994), are found in both the Sturtian and the Varangerian/Marinoan carbonatic successions. These phosphogenic events could be attributed to the high organic productivity following periods of glaciations (Misi et al., 2007).

\subsection{Ediacaran (?) manganese deposits: Barreiras}

The Barreiras manganese province is to the western region of the São Francisco Craton, and extends for about $350 \mathrm{~km}$ in the direction NW-SE. More than 40 deposits and occurrences have been found. Some of these deposits, located near the towns of Barreiras and São Desidério are being explored by Rio Doce Manganês S.A.

The majority of the economic manganese mineralizations occur at the top of the regional Neoproterozoic succession, represented by (i) a miogeossynclinal zone constituted of schist, carbonaceous phyllite, quartzite, siltstone, conglomerate and gondite, (ii) a pericratonic zone with manganese bearing slates and siltstone, and (iii) a cratonic zone also with manganese bearing siltstone and shale, limestone and dolomite Most of these lithologic units are overlain by sandy and argillaceous sediments of the Urucuia Formation (Cretaceous) and by the Tertiary/Quaternary sandstone cover (Barbosa, 1990).

Two types of manganese ores were identified: the ore formed 'in situ' and the eluvial-colluvial/manganese crust ore. X-ray diphratometric analyses have revealed the presence of lithioforite, pyrolusite and cryptomelane in the ore. Spessartite, quartz, clays and micas are the gangue minerals. The genesis of these manganese deposits was attributed to supergenic processes over manganese protore, such as gondite, slate and meta-siltstone (Barbosa, 1990). The age of the weathering process is still unknown.

\subsection{Cambrian diamond in kimberlite: Braúna}

Twenty-one diamondiferous kimberlites were discovered in the Braúna province, central part of the Serrinha block, São Francisco Craton. The province includes three pipes and eighteen complex dike systems that are aligned along the $\mathrm{N} 30 \mathrm{~W}$ direction.

The kimberlite is hosted by the Nordestina Granodiorite, a syntectonic intrusion of the Rio Itapicuru greenstone belt, dated at $2155 \pm 9$ Ma (Mello et al., 2006). The kimberlite mineral assemblage comprises garnet, phlogopite, $\mathrm{Cr}$-spinel, clinopyroxene, and rare ilmenite. $\mathrm{Rb}-\mathrm{Sr}$ dating of phlogopite from one of the kimberlites of the central portion of the Braúna province indicated a cooling age of $682 \pm 20 \mathrm{Ma}$ (Donatti Filho et al., 2008; Pereira and Fuck, 2005).

Kimberlite intrusions carry exotic rock fragments and minerals (including diamond) from upper mantle to the crust. Notwithstanding the Cryogenian cooling age (Pisani et al., 2004), the Braúna kimberlite intrusions are controlled by a NW-SE trending strikeslip fault of Cambrian age. In order to explain the apparent temporal discrepancy one must take into account that the phlogopite flakes must probably preserve early $\mathrm{Rb}-\mathrm{Sr}$ ages recorded at high temperature in the mantle and has preserved its original $\mathrm{Rb}-\mathrm{Sr}$ system acquired during crystallization. A related issue has been addressed by Glodny et al. (2002), regarding the evolution of the $\mathrm{Rb}-\mathrm{Sr}$ system in the Maksyutov Eclogite Complex, Southern Urals, Russia.

High trace element abundance and highly fractionated REE patterns indicate low degree of partial melt and/or a moderate enriched source for the Braúna kimberlites. A partial melting degree of about $0.2-0.3 \%$ indicate derivation of the kimberlite magma from a previously LREE enriched mantle source. Interpretation of these petrological indicators indicated that the intrusions could be the product of partial melting of sub-continental lithospheric mantle, which was previously enriched in metasomatic fluids (Donatti Filho et al., 2008).

\subsection{Cambrian gold deposits: Chapada Diamantina}

Primary gold mineralization in the Serra do Espinhaço and Chapada Diamantina, are associated with quartz veins and boudins, contained within a series of NNW-SSE trending shear zones. These structures are related with a crustal deformation along with thrust 
front dislocations, which resulted from the inversion of the Espinhaço Basin (Cruz and Alkmim, 2006). The country rocks were mylonitized and were strongly affected by intense hydrothermal alteration, with growth of sericite and extensive quartz veining, besides secondary development of hematite and carbonate minerals.

Fluid inclusion studies in quartz grains from samples of selected gold occurrences pointed to an aqueous and aquo-carbonic, low salinity fluid, likely of metamorphic-hydrothermal origin, with greater or lesser involvement of meteoric water. Homogenization temperatures below $300{ }^{\circ} \mathrm{C}$ suggest that the veins crystallized in an epithermal system (Silva et al., 2006a).

Sericite samples collected from the shear zones, immediately adjacent to the veins were subjected to ${ }^{40} \mathrm{Ar}-{ }^{39} \mathrm{Ar}$ analyses that have been performed by Dr. Paulo Vasconcelos at University of Queensland, Brisbane, Australia. The results revealed Cambrian cooling ages, within the range of 497-500 Ma in samples collected in the center of the basin. A sample located in an extension of the shear zones to the area of the basement (Paramirim Complex), yielded an Ordovician (Tremadocian) cooling age of $485 \mathrm{Ma}$ (Silva et al., 2006b).

Besides quartz-gold, other mineralized veins containing barite-hematite and rutilated quartz are also present in the shear zones, and the respective sericite veins provided plateaus of Tremadocian cooling ages.

These mineralizations are related with the Cambrian tectonic reactivation of the area (basement and sedimentary cover) that gave rise to large thrust faults of NW-SE direction. The base of the thickened crust was devolatilized, with generation of hydrothermal fluids rich in metals leached from the country rocks. Migration of these fluids by structurally controlled channelways deposited the mineralized veins in the upper crustal level (Silva et al., 2006a,b).

\section{Discussion and conclusion}

A primary mineral deposit, sensu lato, is not more than a valuable type of rock formed by magmatic, magmatic-hydrothermal or hydrothermal processes in geodynamic systems characterized by anomalously high thermal and/or mechanical energy (Groves and Bierlein, 2007). Mineral provinces consist of groups of mineral deposits confined in specific geodynamic niches, where appropriate geological conditions contributed to their formation and long-term preservation.

The best practice for doing the regional metallogenic analysis and interpretation requires a reasonable understanding of the origin and geodynamic setting of each particular ore deposit and ore province. The main assumption is that an ore deposit stands for the product of specific geodynamic systems and consequently, ore provinces are actual markers of multiple thermotectonic events.

Mineralizing events described in the northern São Francisco Craton occurred between 3300 and $500 \mathrm{Ma}$ and include a diversity of ore deposit types. The Archean blocks have been accreted during the Paleoproterozoic orogenic cycle, and all of these blocks have been previously involved in the assembly and breakup of the Paleoproterozoic Atlantica, the Mesoproterozoic to Neoproterozoic Rodinia, and the Neoproterozoic to Phanerozoic West Gondwana continents (Fig. 4).

Two major phases of crustal shortening with great metallogenic significance were described in the region, represented by (i) the Rhyacian to Orosirian collision belt, with the main deformation and melting of crustal granitoids occurring between 2.15 and $1.8 \mathrm{Ga}$ ago, and (ii) the shortening event of the Brasiliano orogenic cycle, related with the West Gondwana assembling, which has roughly occurred between 640 and 500 Ma ago.

\section{Acknowledgments}

This paper presents part of the results of the project "Digital Metallogenic Map of Bahia", which has been carried out from 2004 to 2006 by the Metallogeny Group of the Federal University of Bahia (UFBA). Funding for the project was provided by the Government of Bahia through Companhia Baiana de Pesquisa Mineral (CBPM). Geological Survey of Brazil (CPRM) and the National Research Agency of Brazil (CNPq) provided additional resources for the research. The authors wish to thank Dr. João Orestes Schneider Santos and a JSAES anonymous reviewer for many suggestions that led to the improvement of the paper.

\section{References}

Abram, M.B., 1994. O corpo máfico-ultramáfico da Fazenda Mirabela, Ipiaú - BA. Sociedade Brasileira de Geologia, Núcleo Bahia/Sergipe, Superintendência de Geologia e Mineração (SGM), Estado da Bahia, Publicação Especial, pp. 58.

Alkmim, F.F., 2004. O que faz de um cráton um cráton? O cráton do São Francisco e as revelações almeidianas ao delimitá-lo. In: Mantesso-Neto, V., Bartorelli, A., Carneiro, C.D.R., Neves, B.B. (Eds.), Geologia do Continente Sul-Americano, Evolução da Obra de Fernando Flávio Marques de Almeida, Beca, São Paulo, pp. $17-35$.

Alkmim, F.F., Marshak, S., Fonseca, M.A., 2001. Assembling west Gondwana in the Neoproterozoic: clues from the São Francisco craton region, Brazil. Geology 29, 319-322.

Almeida, F.F.M., 1977. O cráton do São Francisco. Revista Brasileira de Geociências 7, 349-364.

Alvarenga, C.J.S., Moura, C.A.V., Gorayeb, P.S.S., Abreu, F.A.M., 2000. Paraguay and Araguaia belts. In: Cordani, U.G., Milani, E.J., Thomaz-Filho, A., Campos, D.A. (Eds.), Tectonic Evolution of South America, pp. 183-229. Rio de Janeiro, Brazil.

Arcanjo, J.B.A., Martins, A.M., Loureiro, H.C., Delgado, I.M., Souza, J.D., Neves, J.P. Oliveira, J.E., Teixeira, L.R., Varela, P.H., Gomes, R.D., Santos, R.A., Melo, R.C., 2005. Vale do Paramirim, Bahia: Geologia e recursos minerais. In: Série Arquivos Abertos, vol. 22. Companhia Baiana de Pesquisa Mineral (CBPM). map70.

Bahia Mineração, 2009. www.bamin.com.br.

Barbosa, J.S.F., 1990. O Manganês do Oeste da Bahia (Org.). In: Mascarenhas, J.F. (Ed.) Textos Básicos, 1st ed., vol. 8. SGM - Superintendência de Geologia e Recursos Minerais, Salvador, pp. 76-179.

Barbosa, J.S.F., Sabaté, P., 2004. Archean and Paleoproterozoic crust of the São Francisco craton, Bahia, Brazil: geodynamic features. Precambrian Research 133, $1-27$.

Battilani, G.A., Gomes, N.S., Guerra, W.J., 2007. The occurrence of microdiamonds in Mesoproterozoic Chapada Diamantina intrusive rocks - Bahia/Brazil. Anais Academia Brasileira de Ciências 79, 321-332.

Biondi, J.C., 2003. Processos Metalogenéticos e os Depósitos Minerais Brasileiros. Oficina de Textos, São Paulo, pp. 528.

Bodenlos, A.J. 1954. Magnesite deposits in the Serra das Éguas, Brumado, Bahia, Brazil (Geological Survey Bulletin 975-C). U.S. Government Printing Office, Washington, D.C, pp. 63.

Bossi, J., Gaucher, C., 2004. The Cuchilla Dionisio terrane, Uruguay: an allochthonous block accreted in the Cambrian to SW-Gondwana. Gondwana Research 7, 661-674.

Brito, R.S.C., 2000. Geologia e petrologia do sill máfico ultramáfico do Rio Jacaré Bahia e estudo das mineralizações de $\mathrm{Fe}-\mathrm{Ti}-\mathrm{V}$ e platinóides associados. Unpublished Doctoral Thesis, Universidade de Brasília, pp. 325.

Brito, R.S.C., Nilson, A.A., Laflame, J., 2002. PGM and complex Ni-Fe-Cu-Co arsenide-sulfide paragenesis associated with $\mathrm{Fe}-\mathrm{Ti}-\mathrm{V}$ oxides of the Gulçari magnetitite pod, Rio Jacaré sill, Bahia, Brazil. In: IX International Platinum Symposium, Billings, Montana, USA.

Carvalho, I.G., Iyer, S.S.S., Tassinari, C.C.G., Misi, A., 1997. Lead and sulfur-isotope investigations of the Boquira sediment-hosted sulfide deposits, Brazil. International Geology Review 39, 97-106.

Carvalho Filho, A.R., Queiroz, E.T., Leahy, G.A.S., 1986. Jazida de Cromita de Pedras Pretas, Município de Santa Luz, Bahia (Coords.). In: Schobbenhaus, C., Coelho, C.E.S. (Eds.), Principais Depósitos Minerais Do Brasil, vol. II, Rochas e Minerais Industriais. Brasília, Departamento Nacional de Produção Mineral, pp. 235-248.

Cawood, P.A., 2005. Terra Australis orogen: Rodinia breakup and development of the Pacific and lapetus margins of Gondwana during the Neoproterozoic and Paleozoic. Earth-Science Reviews 69, 249-279.

Chaves, A.O., Tubrettb, M., Rios, F.J., Oliveira, L.A.R., Alvesa, J.V., Fuzikawaa, K., Neves, J.M.C., Matos, E.C., Chaves, A.M.D.V., Prates, S.P., 2007. U-Pb ages related to uranium mineralization of Lagoa Real, Bahia - Brazil: tectonic implications. Revista de Geologia 20, 141-156.

Condie, K.C., 2002. Breakup of a Paleoproterozoic supercontinent. Gondwana Research 5, 41-43.

Cordani, U.G., Iyer, S.S., Taylor, P.N., Kawashita, K., Sato, K., McReath, I., 1992. Pb-Pb, $\mathrm{Rb}-\mathrm{Sr}$, and $\mathrm{K}-\mathrm{Ar}$ systematics of the Lagoa Real uranium province (south- 
central Bahia, Brazil) and the Espinhaço cycle (ca. 1.5-1.0 Ga). Journal of South American Earth Sciences 5, 33-46.

Cordani, U.G., Neves, B.B., D’Agrella-Filho, M.S., 2003. From Rodinia to Gondwana: a review of the available evidence from South America. Gondwana Research 6, 275-283.

Cordani, U.G., Fraga, L.M., Reis, N., Tassinari, C.C.G., Neves, B.B., 2010. On the origin and tectonic significance of the intra-plate events of Grenvillian-type age in South America: a discussion. Journal of South American Earth Sciences 29 (1), 143-159.

Costa, P.H.O., Andrade, A.R.F., Lopes, G.A., Souza, S.L., 1985. Projeto Lagoa Real: Mapeamento Geológico 1:25,000, vol. 12. CBPM, Salvador. + maps.

Cruz, S.C.P., Alkmim, F.F., 2006. The tectonic interaction between the Paramirim Aulacogen and the Araçuaí belt, São Francisco craton region, eastern Brazil. Anais Academia Brasileira de Ciências 78, 151-174.

Cruz, S.C.P., Alkmim, F.F., Leite, C.M.M., Jordt-Evangelista, H., Cunha, J.C., Matos, E.C., Noce, C.M., Marinho, M.M., 2007. Geologia e arcabouço estrutural do Complexo Lagoa Real, vale do Paramirim, centro-oeste da Bahia. Revista Brasileira de Geociências 37 (suplemento), 128-146.

Dardenne, M.A., Schobbenhaus, C., 2003. Depósitos minerais no tempo geológico e épocas metalogenéticas. In: Bizzi, L., Schobbenhaus, C., Vidotti, R.M. Gonçalves, J.H. (Eds.), Geologia, tectônica e recursos minerais do Brasil. CPRM, Brasília, pp. 365-447.

Deus, P.B., Duarte, P.M., Queiroz, W.J.A., 1982. Campo Formoso chromite district. In: International Symposium on Archean and Early Proterozoic Geologic Evolution and Metallogenesis - ISAP, Salvador, Bahia, Brazil, Excursions, pp. 107-114.

Doblas, M., López-Ruiz, J., Cebriá, J.-M., Youbi, N., Degroote, E., 2002. Mantle insulation beneath the west African craton during the Precambrian-Cambrian transition. Geology 30, 839-842.

Donatti Filho, J.P., Oliveira, E., Pisani, J.R., Ochika, F., 2008. Geochemistry and mineralogy of kimberlites from the Braúna kimberlite province, São Francisco Craton, NE Brazil. In: 9th International Kimberlite Conference Extended Abstract No. 9IKC-A-00316.

Dulski, P., Morteani, G., 1989. Magnesite formation by $\mathrm{CO}_{2}$ metasomatism during regional metamorphism of the ultrabasic rocks of the Ochsner serpentinite (Zillertaler Alpen, Tyrol, Austria). In: Möller, P. (Ed.), Magnesite: Geology, Mineralogy, Geochemistry, Formation of Mg-Carbonates. Monograph Series on Mineral Deposits, vol. 8, pp. 95-104.

Evans, D.A.D., 2009. The palaeomagnetically viable, long-lived and all-inclusive Rodinia supercontinent reconstruction. In: Murphy, J.B., Keppie, J.D., Hynes, A. (Eds.), Ancient Orogens and Modern Analogues. Geological Society of London Special Publication, vol. 327, pp. 371-404

Glodny, J., Bingen, B., Austrheim, H., Molina, J.F., Rusin, A., 2002. Precise eclogitization ages deduced from Rb/Sr mineral systematics: the Maksyutov complex, Southern Urals, Russia. Geochimica et Cosmochimica Acta 66, 1221-1235.

Gomes, L.C.C., Oliveira, E.P., 2002. Dados $\mathrm{Sm}-\mathrm{Nd}, \mathrm{Ar}-\mathrm{Ar}$ e $\mathrm{Pb}-\mathrm{Pb}$ de corpos plutônicos no Sudeste da Bahia, Brasil: Implicações para o entendimento da evolução tectônica no limite Orógeno Araçuaí/Cráton do São Francisco. Revista Brasileira de Geociências 32, 185-196.

Goscombe, B.D., Gray, D., 2007. The Coastal Terrane of the Kaoko Belt, Namibia: outboard arc-terrane and tectonic significance. Precambrian Research 155, 139-158.

Groves, D.I., Bierlein, F.P., 2007. Geodynamic setting of mineral deposit systems. Journal of the Geological Society 146, 19-30.

Hedlund, D.C., Moreira, A., Pinto, J.S., Souza, G., 1974. Stratiform chromitite at Campo Formoso, Bahia, Brazil. Journal of Research, U.S. Geological Survey 2, 551-562.

Heilbron, M., Valeriano, C.M., Tassinari, C.C.G., Almeida, J., TupinambáSiga Jr., M.O., Trouw, R., 2008. Correlation of Neoproterozoic terranes between the Ribeira Belt, SE Brazil and its African counterpart: comparative tectonic evolution and open questions. In: Pankhurst, R.J., Trouw, R.A.J., Neves, B.B., De Wit, M.J. (Eds.), West Gondwana: Pre-Cenozoic Correlations Across the South Atlantic Region, vol. 294. Geological Society, London, pp. 211-237. Special Publications

Jacobs, J., Fanning, C.M., Henjes-Kunst, E., Olesch, M., Paech, H.J., 1998. Continuation of the Mozambique belt into east Antarctica: Grenville-age metamorphism and polyphase Pan-African high-grade events in central Dronning Maud Land. Journal of Geology 106, 385-406.

Jacobs, J., Thomas, R.J., 2004. Himalayan-type indenter-escape tectonics model for the southern part of the Late Neoproterozoic-Early Paleozoic East AfricanAntarctic orogen. Geology 32, 721-724.

Johansson, A., 2009. Baltica, Amazonia and the SAMBA connection - 1000 million years of neighbourhood during the Proterozoic? Precambrian Research 175, 221-234.

Largo Resources, 2009. www.largoresources.com.

Ledru, P., Milesi, J.P., Johan, V., Sabaté, P., Maluski, H., 1997. Foreland basins and goldbearing conglomerates: a new model for the Jacobina Basin (São Francisco province, Brazil). Precambrian Research 86, 155-176.

Leite, C.M.M., Barbosa, J.S.F., Goncalves, P., Nicollet, C., Sabaté, P., 2009. Petrological evolution of silica-undersaturated sapphirine-bearing granulite in the Paleoproterozoic Salvador-Curaçá belt, Bahia, Brazil. Gondwana Research 15, 49-70.

Lindenmayer, Z.G., 1981. Evolução geológica do Vale do Rio Curaçá e dos corpos máfico-ultramáficos mineralizados a cobre (Orgs.). In: Inda, H.A.V., Marinho, M.M., Duarte, F.B. (Eds.), Geologia e Recursos Minerais do Estado da Bahia: textos básicos, vol. 4. SME, Salvador, pp. 72-110.

Lobato, L.M., 1985. Metamorphism, metasomatism and mineralization at Lagoa Real, Bahia, Brazil. PhD Thesis, University of Western Ontario, London, Canada.
Lobato, L.M., Fyfe, W.S., 1990. Metamorphism, metasomatism, and mineralization at Lagoa Real, Bahia, Brazil. Economic Geology 85, 968-989.

Maier, W.D., Barnes, S.J., 1999. The origin of Cu sulfide deposits in the Curaçá valley, Bahia: evidence from $\mathrm{Cu}, \mathrm{Ni}, \mathrm{Se}$, and platinum-group element concentrations. Economic Geology 94, 165-183.

Marques, J.C., Ferreira Filho, C.F., 2003. The chromite deposit of the Ipueira-Medrado sill, São Francisco craton, Bahia State, Brazil. Economic Geology 98, 87-108.

Marshak, S., Alkmim, F.F., Whittington, A., Pedrosa-Soares, A.C., 2006. Extensiona collapse in the Neoproterozoic Araçuaí orogen, eastern Brazil: a setting for reactivation of asymmetric crenulation cleavage. Journal of Structural Geology 28, 129-147.

Maruèjol, P., Cuney, M., Fuzikawa, K., Netto, A.M., Poty, B., 1987. The Lagoa Real subalcaline granitic complex (South Bahia, Brazil): a source for uranium mineralizations associated with $\mathrm{Na}-\mathrm{Ca}$ metasomatism. Revista Brasileira de Geociências 17, 578-594.

Mascarenhas, J.F., Ledru, P., Souza, S.L., Conceição Filho, V.M., Melo, L.F.A Lorenzo, C.L., Milesi, J.P., 1998. Geologia e recursos minerais do Grupo Jacobina e da parte sul do greenstone belt de Mundo Novo. In: Série Arquivos Abertos, vol. 13. Companhia Baiana de Pesquisa Mineral (CBPM). 58.

Mascarenhas, J.F., Silva, E.F.A., 1994. Greenstone belt de Mundo Novo: Caracterização e implicações metalogenéticas e geotectônicas no cráton do São Francisco. In: Série Arquivos Abertos, vol. 5. Companhia Baiana de Pesquisa Mineral-CBPM, Salvador. 31 map.

McIver, J.R., McCarthy, T.S., Packham, B.V., 2004. The copper-bearing basic rocks of Namaqualand, South Africa. Mineralium Deposita 18, 135-160.

Meert, J.G., 2001. Growing Gondwana and rethinking Rodinia: a paleomagnetic Perspective. Gondwana Research 4, 279-288.

Mello, E.F., Xavier, R.P., McNaughton, N.J., Hagemann, S.G., Fletcher, I., Snee, L., 2006 Age constraints on felsic intrusions, metamorphism and gold mineralisation in the Palaeoproterozoic Rio Itapicuru greenstone belt, NE Bahia State, Brazil. Mineralium Deposita 40, 849-866.

Mirabela Nickel Ltd, 2009. Prospectus. www.mirabela.com.au.

Misi, A., Kyle, J.R., 1994. Upper Proterozoic carbonate stratigraphy, diagenesis, and stromatolitic phosphorite formation, Irecê Basin, Bahia, Brazil. Journal of Sedimentary Research A64, 299-310.

Misi, A., Iyer, S.S., Tassinari, C.C.G., Kyle, J.R., Coelho, C.E.S., Franca-Rocha, W.J.S., Gomes, A.S.R., Cunha, I.A., Carvalho, I.G., 1999. Geological and isotopic constraints on the metallogenic evolution of the Proterozoic sediment hosted $\mathrm{Pb}-\mathrm{Zn}(\mathrm{Ag})$ deposits of Brazil. Gondwana Research 2, 47-65.

Misi, A., Iyer, S.S., Coelho, C.E.S., Tassinari, C.C.G., Franca-Rocha, W.J.S., Cunha, I.A., Gomes, A.S.R., Oliveira, T.F., Teixeira, J.B.G., Conceição Filho, M., 2005. Sediment hosted lead-zinc deposits of the Neoproterozoic Bambuí Group and correlative sequences, São Francisco Craton, Brazil: a review and a possible metallogenic evolution model. Ore Geology Reviews 26, 263-304.

Misi, A., Kaufman, A.J., Veizer, J., Powis, K., Azmy, K., Boggiani, P.C., Gaucher, C., Teixeira, J.B.G., Sanches, A.L., Iyer, S.S.S., 2007. Chemostratigraphic correlation of Neoproterozoic successions in South America. Chemical Geology 237, 143-167.

Neves, B.B., Campos-Neto, M.C., Fuck, R.A., 1999. From Rodinia to Western Gondwana: an approach to the Brasiliano-Pan African cycle and orogenic collage. Episodes 22, 155-166.

Neves, B.B., Santos, E.J., Van Schmus, W.R., 2000. Tectonic history of the Borborema province, northeastern Brazil. In: Cordani, U.G., Milani, E.J., Thomaz-Filho, A., Campos, D.A. (Eds.), Tectonic Evolution of South America, pp. 151-182. Rio de Janeiro, Brazil.

Niedermayr, G., Beran, A., Brandstätter, F., 1989. Diagenetic type magnesites in the Permo-Scythian rocks of the eastern Alps, Austria. In: Möller, P. (Ed.), Magnesite: Geology, Mineralogy, Geochemistry, Formation of Mg-Carbonates. Monograph Series on Mineral Deposits, vol. 28, pp. 35-59.

Ogg, J., Ogg, G., Gradstein, F., 2008. The Concise Geologic Time Scale. Cambridge University Press, U.K., pp. 184.

Oliveira, E.P., Escayola, M., Souza, Z.S., Bueno, J.F., Araújo, M.G.S., McNaughton, N. 2007. The Santa Luz chromite-peridotite and associated mafic dykes, BahiaBrazil: remnants of a transitional-type ophiolite related to the Paleoproterozoic ( $>2.1 \mathrm{Ga}$ ) Rio Itapicuru greenstone belt? Revista Brasileira de Geociências 37 (suplemento), 28-39.

Oliveira, E.P., Windley, B.F., McNaughton, N., Pimentel, M., Fletcher, I.R., 2004. Contrasting copper and chromium metallogenic evolution of terranes in the Paleoproterozoic Itabuna-Salvador-Curaçá orogen, São Francisco Craton, Brazil: new zircon (SHRIMP) and Sm-Nd (model) ages and their significance for orogen-parallel escape tectonics. Precambrian Research 128, 143-165.

Oliveira, V.P., Ciminelli, R., 1997. Depósitos de talco da Serra das Éguas, Brumado, Bahia (Coords.). In: Schobbenhaus, C., Queiroz, E.T., Coelho, C.E.S. (Eds.), Principais depósitos minerais do Brasil, vol. 4C, Rochas e Minerais Industriais. Departamento Nacional de Produção Mineral, Brasília, pp. 545-549.

Oliveira, V.P., Fragomeni, L.F.P., Bandeira, C.A., 1997. Depósitos de magnesita de Serra das Éguas, Brumado, Bahia (Coords.). In: Schobbenhaus, C., Queiroz, E.T. Coelho, C.E.S. (Eds.), Principais Depósitos Minerais Do Brasil. Rochas e Minerais Industriais, vol. 4C. Departamento Nacional de Produção Mineral, Brasília, pp. 219-234.

Pereira, R.S., Fuck, R.A., 2005. Archean nucleii and the distribution of kimberlite and related rocks in the São Francisco Craton, Brazil. Revista Brasileira de Geociências 35, 93-104.

Peucat, J.J., Mascarenhas, J.F., Barbosa, J.S.F., Souza, S.L., Marinho, M.M., Fanning, C.M., Leite, C.M.M., 2002. 3.3 Ga SHRIMP U-Pb zircon age of a felsic metavolcanic rock 
from the Mundo Novo greenstone belt in the São Francisco Craton, Bahia (NE Brazil). Journal of South American Earth Sciences 15, 363-373.

Pimentel, M.M., Fischel, D.P., Fuck, R.A., 2000. U-Pb data for granulites of the Anápolis-Itauçu Complex: evidence for two high-grade events in the Brasília Belt. Anais Academia Brasileira de Ciências 72, 604-605.

Pimentel, M.M., Machado, N., Lobato, L.M., 1994. Geocronologia U/Pb de rochas graníticas e gnáissicas da região de Lagoa Real, Bahia e implicações para a idade da mineralização de Urânio. In: Congresso Brasileiro de Geologia, Camboriú. Boletim dos Resumos Expandidos, vol. 2. Sociedade Brasileira de Geologia, pp. 389-390.

Pisani, J.R.T., Tainton, K.M., Allan, A.F., Silva, S.B., Miranda, J.V., 2004. Geology and exploration of the Braúna diamondiferous kimberlites, Serrinha block, BahiaBrazil. http://majescor.com/presentations/brauna092004.pdf.

Rapela, C.W., 2000. The Sierras Pampeanas of Argentina: Paleozoic building of the southern proto-Andes. In: Cordani, U.G., Milani, E.J., Thomaz-Filho, A. Campos, D.A. (Eds.), Tectonic Evolution of South America, Rio de Janeiro, Brazil, pp. 381-387.

Rapela, C.W., Pankhurst, R.J., CasquetFanning, C.M., Baldo, E.G., GonzálezCasado, J.M., Galindo, C., Dahlquist, J., 2007. The Río de la Plata Craton and the assembly of SW Gondwana. Earth-Science Reviews 83, 49-82.

Ribeiro Filho, E., 1974. Geologia da mina de manganês Pedra Preta, Urandi, Bahia. Boletim IG-USP 5, 47-55.

Rocha, G.M.F. Souza, S.L. Garrido, I.A.A 1998. Distrito manganesífero de Urandi-Licínio de Almeida, Bahia: Geologia e potencialidade econômica. In: Série Arquivos Abertos, vol. 12. Companhia Baiana de Pesquisa Mineral (CBPM). 34 map.

Santana, A.J., Moreira, M.D., Couto, P.A.A., 1995. Esmeralda de Carnaíba e Socotó, Bahia: Geologia e Potencialidade Econômica. In: Série Arquivos Abertos, vol. 26 CBPM-Companhia Baiana de Pesquisa Mineral. 26 map.

Schmitt, R.S., Trouw, R.A.J., Van Schmus, W.R., Pimentel, M.M., 2004. Late amalgamation in the central part of Western Gondwana: new geochronological data and the characterization of a Cambrian collision orogeny in the Ribeira Belt (SE Brazil). Precambrian Research 133, 29-61.

Schobbenhaus, C., Gonçalves, J.H., Santos, J.O.S., Abram, M.B., Leão Neto, R. Matos, G.M.M., Vidotti, R.M., Ramos, M.A.B., Jesus, J.D.A., 2004. Carta Geológica do Brasil ao Milionésimo, Sistema de Informações Geográficas - GIS and 48 maps 1:1,000,000. CPRM, Brasília, pp. 41 CD-ROMs.

Silva, A.J.C.L.P., 1994. O Supergrupo Espinhaço na Chapada Diamantina centrooriental, Bahia: Sedimentologia, estratigrafia e tectônica. Doctoral Thesis, Universidade de São Paulo, SP, Brazil, pp. 174.

Silva, A.J.C.L.P., 2001. Serra do Sincorá, Bahia. In: Schobbenhaus, C., Campos, D.A Queiroz, E.T., Winge, M., Berbert-Born, M. (Eds.), Sítios Geológicos e Paleontológicos do Brasil. DNPM/CPRM, Comissão Brasileira de Sítios Geológicos e Arqueológicos (SIGEP), pp. 187-194.

Silva, L.C., McNaughton, N.J., Melo, R.C., Fletcher, I.R., 1997. U-Pb SHRIMP ages in the Itabuna-Caraíba TTG high-grade Complex: the first window beyond the Paleoproterozoic overprinting of the eastern Jequié Craton, NE Brazil. In: ISGAM International Symposium on Granites and Associated Mineralizations, Salvador vol. 2, pp. 282-283.

Silva, L.J.H.D'el-Rey, Dantas, E.L., Teixeira, J.B.G., Laux, J.L., Silva, M.G., 2007. U-Pb and Sm-Nd geochronology of amphibolites from the Curaçá belt, São Francisco craton, Brazil: tectonic implications. Gondwana Research 12, 454-467.
Silva, L.J.H.D'el-Rey, Oliveira, J.G., 1999. Geology of the Caraíba mine and its surroundings in the Paleoproterozoic Curaçá belt - Curaçá river valley, Bahia, Brazil (Orgs.). In: Silva, M.G., Misi, A. (Eds.), Base Metal Deposits of Brazil, pp. 25-32.

Silva, M.G., Martin, H., Abram, M.B., 1996. Datação do corpo máfico ultramáfico da Faz. Mirabela (BA) pelo método Sm-Nd: Implicações petrogenéticas e geotectônicas. In: SBG, Congresso Brasileiro de Geologia, vol. 39, Salvador. Anais 6, 217-220.

Silva, M.G., Cunha, J.C. 1999. Greenstone Belts and equivalent volcano-sedimentary sequences of the São Francisco Craton, Bahia, Brazil - Geology and mineral potencial (Orgs.). In: Silva, M.G., Misi, A. (Eds.), Base Metal Deposits of Brazil. Ministério das Minas e Energia, Belo Horizonte, pp. 1-108.

Silva, M.G., Coelho, C.E.S., Teixeira, J.B.G., Silva, F.C.A., Silva, R.A., Souza, J.A.B., 2001 The Rio Itapicuru greenstone belt, Bahia, Brazil: geologic evolution and review of gold mineralization. Mineralium Deposita 36, 345-357.

Silva, M.G., Neves, J.P., Klein, E., Bento, R.V., Dias, V.M., 2006a. Principais processos envolvidos na gênese das mineralizações de $\mathrm{Sn}$. $\mathrm{Au}$, Ba, quartzo rutilado e diamante, na região do Espinhaço-Chapada Diamantina, Bahia. In: XLIII Congresso Brasileiro de Geologia, 2006, Aracaju. Anais do XLIII Congresso Brasileiro de Geologia, p. 161.

Silva, M.G., Guimarães, J.T., Teixeira, L., Martins, A.M., Andrade Filho, E.L., Loureiro, H., Arcanjo, J.B., Neves, J.P., Mascarenhas, J.F., Melo, R.C., Bento, R.V., 2006b. Evidências estruturais, metalogenéticas e geocronológicas da inversão neoproterozóica do rifte Espinhaço. In: XLIII Congresso Brasileiro de Geologia, 2006, Aracaju. Anais do XLIII Congresso Brasileiro de Geologia, p. 177.

Tassinari, C.C.G., Bettencourt, J.S., Geraldes, M.C., Macambira, M.J.B., Lafon, J.M., 2000. The Amazonian craton. In: Cordani, U.G., Milani, E.J., Thomaz-Filho, A., Campos, D.A. (Eds.), Tectonic Evolution of South America, Rio de Janeiro, Brazil. pp. 41-95.

Teixeira, J.B.G., Kishida, A., Marimon, M.P.C., Xavier, R.P., McReath, I., 1990. The Fazenda Brasileiro gold deposit, Bahia: geology, hydrothermal alteration, and fluid inclusion studies. Economic Geology 85, 990-1009.

Teixeira, J.B.G., Souza, J.A.B., Silva, M.G., Leite, C.M.M., Barbosa, J.S.F., Coelho, C.E.S., Abram, M.B., 2001. Gold mineralization in the Serra de Jacobina region, Bahia, Brazil: tectonic framework and metallogenesis. Mineralium Deposita 36, 332-344.

Teixeira, J.B.G., Vasconcelos, P.M., Misi, A., 2002. Geodynamic setting of orogenic gold deposits in the Atlantica paleocontinent. In: 11th Quadrennial IAGOD Symposium and Geocrongress 2002, Windhoek, Namibia Extended Abstracts (CD-ROM).

Teixeira, J.B.G., Misi, A., Silva, M.G., 2007. Supercontinent evolution and the Proterozoic metallogeny of South America. Gondwana Research 11, 346-361.

Trindade, R.I.F., D’Agrella-Filho, M., Babinski, M., Neves, B.B., 2004. Paleomagnetism and geochronology of the Bebedouro cap carbonate: evidence for continentalscale Cambrian remagnetization in the São Francisco Craton, Brazil. Precambrian Research 128, 83-103.

Turpin, L., Maruèjol, P., Cuney, M., 1988. U-Pb, Rb-Sr and Sm-Nd chronology of granitic basement, hydrothermal albitites and uranium mineralization (Lagoa Real, South-Bahia, Brazil). Contributions to Mineralogy and Petrology 98, 139-147.

Yamana Gold, 2009. www.yamana.com. 